\title{
Using the Ventrogluteal Site for Intramuscular Injection
}

\author{
Aynur Kaynar Şimşek, (D) Şule Ecevit Alpar \\ Department of Nursing, Marmara University Faculty of Health Sciences, Istanbul, Turkey
}

\section{ABSTRACT}

Intramuscular (IM) injection is one of the most common invasive procedures performed by nurses. Many complications due to unsafe IM injections have been reported in the literature. Most of these complications develop due to injections into the dorsogluteal (DG) site. Recent studies conducted to increase safe injection applications have determined that the DG site is the most risky region for IM injections because it is close to sciatic nerves, may have subcutaneous adipose tissue thick enough to prevent access to target muscles, and allows to detect injection site only with imaginary lines. However, the ventrogluteal (VG) site has been reported as the most reliable region for and suggested as the first choice of IM injections because it is far from sciatic nerves, receives the blood from small branches of arteries, allows detecting injection site by palpating bone structures, and has subcutaneous adipose tissue thin enough to reach target muscles. Despite the changes in the literature regarding site selection for IM injections, studies have reported that nurses prefer the DG site as the first choice for administering IM injections. In addition, studies of the reasons why nurses prefer the DG site for IM injections have emphasized that they do not have adequate knowledge of VG injections. This study was conducted to explain the reasons why the IM site should be preferred for administering IM injections to increase the level of knowledge on the administration of IM injections into the IM site and to raise the use of the IM site for administering IM injections.

Keywords: Intramuscular injection, nursing, patient safety

Please cite this article as: Kaynar Şimşek A, Ecevit Alpar Ş. Using the Ventrogluteal Site for Intramuscular Injection. Anatol J Family Med 2020;3(3):195-199.

Address for correspondence: Dr. Aynur Kaynar Şimşek. Department of Nursing, Marmara University Faculty of Health Sciences, Istanbul, Turkey

Phone: +90 5304642743

E-mail:

aynurkaynarsimsek@hotmail.com

Received Date: 02.03.2020

Accepted Date: 15.04 .2020

Published online: 04.11.2020

(C) Copyright 2020 by Anatolian Journal of Family Medicine -

Available online at

WwW.anatoljfm.org

OPEN ACCESS

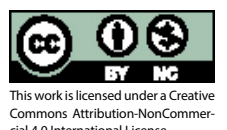

\section{INTRODUCTION}

Intramuscular (IM) injection, which is one of the parenteral drug administration routes, is one of the invasive procedures performed by nurses. It is a safe route to administer drugs with high concentrations and severe irritant effects whose absorption is desired to be fast via a subcutaneous route and slow via venous route. IM injection refers to the injection of drugs into deep muscle tissue beneath the subcutaneous tissue. ${ }^{[1,2]} \mathrm{IM}$ injections were first administered in the 1940s by physicians familiar with antibiotics. In Turkey, IM injections started to be administered by nurses in accordance with the Nursing Law at 1954*. Today, it is among the most frequently applied nursing interventions. ${ }^{[3]}$ Although IM injection is considered a simple procedure, it is a complex procedure requiring special knowledge and psychomotor skills. ${ }^{[4,5]}$ If it is not performed safely, it may cause serious complications, increasing patient morbidity and mortality, which may bring nurses to ethical issues and justice. ${ }^{[1,6]}$

Until recently, the dorsogluteal (DG) site is the most commonly used IM injection site in adults. ${ }^{[7-11]}$ However, recent studies have emphasized that the DG site should not be used for IM injections, instead, the ventrogluteal (VG) site, a safer body surface, should be preferred..$^{[1-4,6,10,12-16]}$

Despite the high risk of complications, nurses continue to prefer the DG site as the first choice 
for administering IM injections. ${ }^{[8-10,14,17,18]}$ However, nurses are entirely responsible for administering safe injections. Healthcare professionals should have the necessary knowledge and skills to administer injections to prevent damage to patients and their families and to protect themselves against the law. ${ }^{[19]}$

This study was conducted to explain the reasons why the VG site, which is recommended as the first choice of IM injection sites. ${ }^{[2-4,10,14-16]}$ Unfortunately, reported as the least used site for administering IM injections both in Turkey and across the world, should be suggested for administering IM injections, to increase the level of knowledge on the administration of IM injections into the VG site, and to raise the use of VG site for administering IM injections. ${ }^{[8,17,18]}$

\section{Why the VG site?}

The most important determinant of a safe injection is the selection of the proper injection site. ${ }^{[12,16,20,21]}$ A selection of the wrong site for IM injection may cause many complications, including skeletal muscle fibrosis and contracture due to injection of excess drugs into small muscles, abscess due to injection of drugs into subcutaneous tissue instead of muscle tissue, adverse drug reactions due to intravenous injection of drugs instead of IM injection, sciatic neuropathy due to incorrect injection site detection or different anatomic structure of sciatic nerves, and nerve-bone injuries due to incorrect injection site detection. ${ }^{[6,7,11,22]}$ Since the drugs with high concentration/irritant effects or more than $2 \mathrm{ml}$. are administered via IM route, gluteal muscles, which are the thickest muscles, should be used for the injections. The injection sites with gluteal muscles are the DG and VG sites. $^{[12]}$

The target muscle in the DG site is the gluteus maximus. Nurses use the DG site as the first choice of IM injections. ${ }^{[8-11]}$ However, the DG site is the most risky region for IM injections, because: ${ }^{[6,12,13,23,24]}$

- There are variations in the anatomical structure of the sciatic nerve in this site,

- The majority of the injections considered to be administered intramuscularly are actually administered into subcutaneous adipose tissue,

- The subcutaneous adipose tissue is thick enough to prevent access to target muscles,

- A wrong site can be selected due to the detection of the injection site with imaginary lines.

The VG site (anterolateral/lateral hip) includes gluteus medius and minimus muscles. Despite its first use as an IM in- jection site in the early 1950s, this site is not often preferred for administering IM injections today. However, the VG site is the most reliable region for IM injections, because: $:^{[1-4,10,14-16]}$

- The risk of nerve damage in this site is very low because it is far from sciatic nerves and inversed by small nerve branches,

- It receives the blood from small branches of arteries,

- It is rarely exposed to fecal contamination,

- It has the thickest muscle layer consisting of both gluteus medius and minimus muscles,

- The gluteus medius muscles in this site are sufficiently developed even in infants,

- It allows detecting injection site by palpating bone structures,

- It allows administering injections in supine, prone or lateral positions,

- It is suitable even for injections of high volume, dense or irritating drugs,

- The subcutaneous adipose tissue is thin enough to allow access to target muscles.

The VG site should be the first choice of IM injection site for individuals with a body mass index between $18.5-29.9 \mathrm{~kg} /$ $\mathrm{m}^{2} \cdot{ }^{[1-4,10,14-16]}$ Nurses should be careful in administering IM injections to individuals with a body mass index between $30.0-40.0 \mathrm{~kg} / \mathrm{m}^{2}$ and be sure of the accuracy of the injection site. ${ }^{[2-4,10,14-16,25]}$

\section{VG Injection}

The patient can lie in supine, prone, or lateral positions for IM injection. To relax the muscles during the injection, the patient lying in the supine position should flex his/her knees (Figure 1a), the patient lying in the prone position should turn his/her feet inward by facing thumbs each other (Figure 1b), and the patient lying in the lateral position should flex his/her upper leg and place it in front of the lower leg (Figure 1c). ${ }^{[1,5,11,15]}$

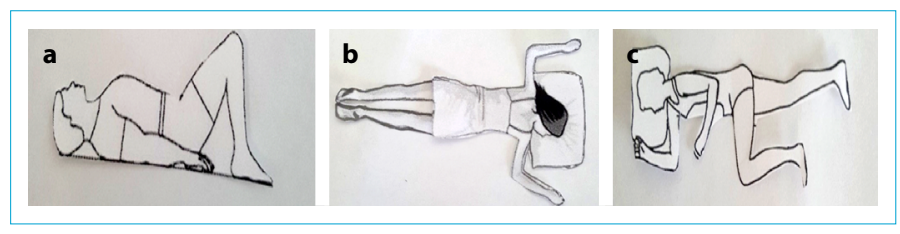

Figure 1. (a) Supine, (b) Prone, (c) Lateral. Positions for ventrogluteal injection. 
IM injection administration technique,

- Drugs and necessary materials are prepared. ${ }^{[4,26-31]}$

- Site detection: If the left hip is used for injection, the right hand's palm; otherwise, the left hand's palm is placed on the greater trochanteric fracture protrusion of the femur. The index finger is placed on the anterior superior iliac spine while other fingers are opened as far back as possible to form a " $\mathrm{V}$ " region (the midpoint of the "V" region is the injection site) (Figure 2). ${ }^{[28-31]}$

- A cotton pad/sponge moistened with antiseptic is placed on the designated area (to mark the detected site). ${ }^{[31]}$

- The needle guard is taken off and the syringe is held like a pen/dart. ${ }^{[26-28,31]}$

- The site determined is wiped with an antiseptic solution in circular movements from inside to outside with a diameter of about $5 \mathrm{~cm}$, and allowed to dry for $30 \mathrm{sec}-$ onds. $^{[27,29,31]}$

\section{If the Z-technique is used,}

- The skin is stretched to one side by $2-3 \mathrm{~cm}$ using the non-dominant hand (Figure 3a). ${ }^{[30,31]}$

- The needle is held towards the skin surface at a 90-degree angle using the dominant hand (Figure 3b). ${ }^{[29-31]}$

- The needle is inserted into the skin at a 90-degree angle using the dominant hand (Figure 3c). ${ }^{[26,29,30]}$

- The lower end of the syringe is held by the thumb and forefinger of the hand that continues to stretch the tissue, and the plunger is pulled back by the other hand

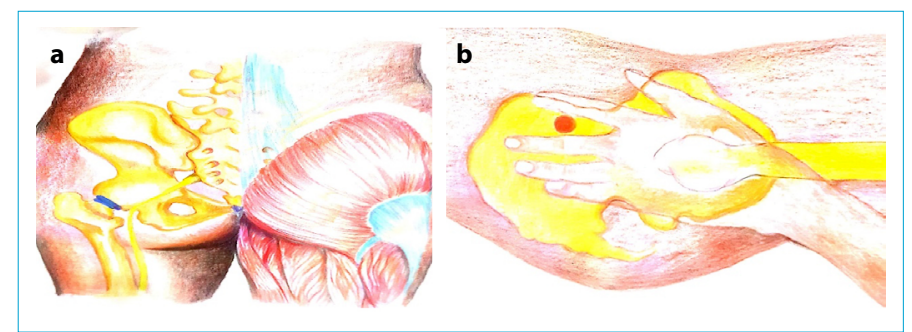

Figure 2. Ventrogluteal site detection.

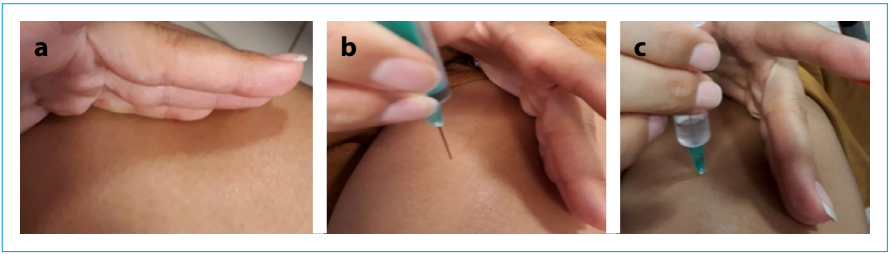

Figure 3. Intramuscular injection with $\mathrm{Z}$ technique.
(5-10 seconds) to see if the blood comes back into the syringe. . $^{[4,30,31]}$

\section{If the Z-technique is not used,}

- The skin is stretched slightly by the thumb and forefinger of the non-dominant hand (Figure 4a). ${ }^{[28,29]}$

- The needle is inserted into the skin at a 90-degree angle using the dominant hand (Figure 4b). ${ }^{[26,29]}$

- After the needle is inserted, the skin is released, holding the lower end of the syringe by the thumb and forefinger. The plunger is pulled back ( $5-10$ seconds) by the other hand to see if the blood comes back into the syringe. ${ }^{[30,31]}$

\section{If the blood does not come back into the syringe,}

- The drug is injected into the skin in such a way that $1 \mathrm{ml}$ of the drug is delivered at 10 seconds by pressing the plunger. ${ }^{[26,27,29-31]}$

- It is waited for 10 seconds after drug administration. ${ }^{[2,29-31]}$

- A dry cotton pad is pressed lightly on the site, and the needle is swiftly withdrawn without disturbing the injection angle. ${ }^{[29,31]}$

- The injection site is pressurized for a while by using a dry cotton tampon/sponge. ${ }^{[30,31]}$

- The patient is provided with a comfortable position. ${ }^{[29,31]}$

\section{Needle Selection for VG Injection}

It is important to select a needle with the right length and gauge for IM injection. ${ }^{[26]}$ The length of the needle should be determined by considering the individual's body mass index. The $16-25 \mathrm{~mm}, 25 \mathrm{~mm}$ and $25-38 \mathrm{~mm}$ needles are used to administer VG injections in underweight $(\mathrm{BMI}<18.5$ $\left.\mathrm{kg} / \mathrm{m}^{2}\right)$, normal weight $\left(\mathrm{BMl}=18.5-24.9 \mathrm{~kg} / \mathrm{m}^{2}\right)$ and overweight $\left(\mathrm{BMI}=25.0-29.9 \mathrm{~kg} / \mathrm{m}^{2}\right)$ individuals, respectively. The gauge should be determined according to drug concentration. A 22-25 gauge needle should be selected for injection of diluted drugs, whereas an 18-21 gauge needle should be selected for injection of dense or oily drugs. ${ }^{[26,30]}$

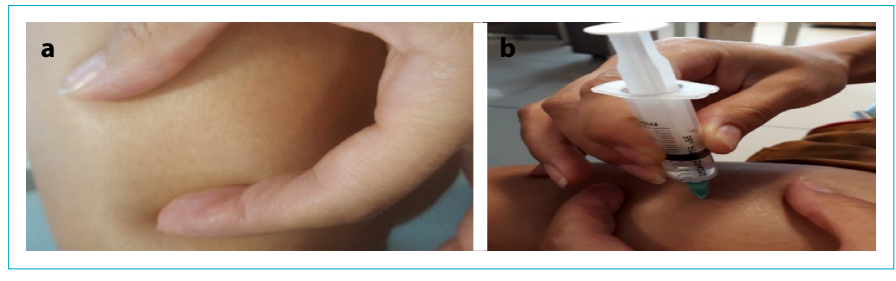

Figure 4. Intramuscular injection administration method without using the $Z$ technique. 


\section{Improving Patient Comfort in VG Injection}

Some pain is expected during IM injections due to the entry of a foreign body into muscles and the injection of a non-physiological substance. ${ }^{[2,15,27]}$ However, it may be possible to increase patient comfort and reduce pain and risk of complications using the following techniques during the injection:

- To use necessary techniques for making the patient relax his/her muscles during the injection (Figure 1), $[2,26,27]$

- To use $Z$ technique for the injection of irritant drugs, ${ }^{[26,27]}$

- To change the needle after taking the drug, ${ }^{[2,31]}$

- Not to administer IM injection into atrophic muscles, ${ }^{[2,26]}$

- To wait for the antiseptic to dry before injecting. ${ }^{[27,29]}$

\section{CONCLUSION}

The sciatic nerve, which is the largest and longest nerve in the body, originates from the L4 and S3 nerve roots, providing innervation of posterior thigh muscles and all sensory and motor functions below the knee. As it innervates the knee flexors and all muscle groups below the knee, this nerve affects the hip and knee flexion and adduction, all movements at the ankle joint and foot level, and Achilles tendon reflexes.

Recent studies have reported that serious complications, such as sciatic nerve injury, are possible to develop during IM injections due to the type of injection site and pharmaceutical properties, and most of these complications develop because of DG injections. Thus, this site should not be preferred for IM injections. In this regard, it should be noted that the undesirable damages of IM injections administered into the DG site will be considered malpractice, and can cause not only conscientious responsibility but also legal sanctions. ${ }^{[23]}$

\section{Disclosures}

Peer-review: Externally peer-reviewed.

Conflict of Interest: None declared.

Authorship contributions: Concept - A.K.Ş.; Design - A.K.Ş., Ş.E.A.; Supervision - Ş.E.A.; Literature search - A.K.Ş.; Writing A.K.Ş.; Critical Review - Ş.E.A.

\section{REFERENCES}

1. Doğu Ö. Buz dağının görünmeyen yönü; ventrogluteal bölge ne kadar kullanılıyor? Hemşirelikte Eğitim ve Araştırma Dergisi 2016;13(1):7-10.

2. Uysal N, Çakırcalı E. Hemşirelik esasları insan sağlığı fonksiyonları. Ankara: Palme Yayıncılık; 2015. p. 398-468.

3. Coskun $\mathrm{H}$, Kilic $\mathrm{C}$, Senture $\mathrm{C}$. The evaluation of dorsogluteal and ventrogluteal injection sites: a cadaver study. J Clin Nurs 2016;25(7-8):1112-9. [CrossRef]

4. Nicoll LH, Hesby A. Intramuscular injection: an integrative research review and guideline for evidence-based practice. applied Nursing Research 2002;16(2):149-62. [CrossRef]

5. Kacaroğlu VA, Sü S, Alpar ŞE. İntramüsküler enjeksiyonda ventrogluteal bölgenin kullanımı. Yıldırım Beyazıt Üniversitesi Sağlık Bilimleri Fakültesi Hemşirelik E-Dergi 2015;3(2):56-61.

6. Currin SS, Mirjalili SA, Meikle G, Stringer MD. Revisiting the surface anatomy of the sciatic nerve in the gluteal region. Clin Anat 2015;28(1):144-9. [CrossRef]

7. Kaya K, Çekin N. Enjeksiyon sonrası gelişen nöropati: komplikasyon/malpraktis ayrımında ince bir çizgi. KSÜ Tıp Fak Der 2018;13(2):63-6. [CrossRef]

8. Gülnar $\mathrm{E}$, Özveren H. An evalution of the effectiveness of a planned training program for nurses on administering intramuscular injection into the ventrogluteal site. Nurse Education Today 2016;36:360-3. [CrossRef]

9. Wynaden D, Tohotoa J, Al Omari O, Happell B, Heslop K, Barr $\mathrm{L}$, et al. Administering intramuscular injections: how does research translate into practice over time in the mental health setting? Nurse Educ Today 2015;35(4):620-4. [CrossRef]

10. Walsh L, Brophy K. Staff nurses' sites of choice for administering intramuscular injections to adult patients in the acute care setting. J Adv Nurs 2011;67(5):1034-40. [CrossRef]

11. Yavuz DE, Karabacak Ü. İntramüsküler enjeksiyonda neden ventrogluteal bölgeyi tercih etmeliyiz? Hemşirelikte Araştırma Geliştirme Dergisi 2011;(2):81-8.

12. Chan VO, Colville J, Persaud T, Buckley O, Hamilton S, Torreggiani WC. Intramuscular injections into the buttocks: are they truly intramuscular? Eur J Radiol 2006;58(3):480-4. [CrossRef]

13. Larkin TA, Ashcroft E, Elgellaie A, Hickey BA. Ventrogluteal versus dorsogluteal site selection: A cross-sectional study of muscle and subcutaneous fat thicknesses and an algorithm incorporating demographic and anthropometric data to predict injection outcome. Int J Nurs Stud 2017;71:1-7. [CrossRef]

14. Hopkins U, Arias CY. Large-volume IM injections: A review of best practices. oncology nurse advisor 2013;4:32-7.

15. Zimmermann PG. Revisiting IM injections the ventrogluteal site is the safest for intramuscular injections. Am J Nurs 2010;110(2):60-1. [CrossRef]

16. Cocoman A, Murray J. Intramuscular injections: a review of best practice for mental health nurses. J Psychiatr Ment Health Nurs 2008;15(5):424-34. [CrossRef]

17. Gülnar E, Çalışkan N. Hemşirelerin ventrogluteal bölgeye intramüsküler enjeksiyon uygulamasına yönelik bilgi düzeylerinin belirlenmesi. DEUHYO ED 2014;7(2):70-7.

18. Greenway K. Using the ventrogluteal site for intramuscular injection. Nurs Standart 2004;18(25):39-42. [CrossRef] 
19. Uslusoy EÇ, Duran ET, Korkmaz M. Güvenli enjeksiyon uygulamaları. Hacettepe Üniversitesi Hemşirelik Fakültesi Dergisi 2016;3(2):50-7.

20. Pandian JD, Bose S, Daniel V, Singh Y, Abraham AP. Nerve injuries following intramuscular injections: a clinical and neurophysiological study from Northwest India. J Peripher Nerv Syst 2006;11:165-71. [CrossRef]

21. Kara D, Uzelli D, Karaman D. Ventrogluteal site in ıntramuscular Injections is a priority or an alternative? International Journal of Caring Sciences 2015;8(2):507-8.

22. Bağış $S$, Adam M, Leblebici ÜB, Karataş $M$, Güven $A Z$, Çeliker AR. Sciatic nerve injury due to intramuscular injection: electrophysiological findings and one-year follow-up. Turk J Med Sci 2012;42(5):913-7.

23. Kaya N, Turan N, Palloş AÖ. Dorsogluteal bölge intramusküler enjeksiyon uygulamak amacıyla kullanılmamalı mı? İ.Ü.F.N. Hem Derg 2012;20(2):146-53.

24. Altıok M, Kuyurtar F, Gökçe H, Taşdelen B. Birinci basamak sağlık hizmetinde çalışan ebe ve hemşirelerin intramuskuler enjeksiyonuna yönelik bilgileri. Fırat Sağlık Hizmetleri Dergisi 2007;2(4):69-84.

25. Güneş ÜY, Zaybak A, Tamsel S. Ventrogluteal bölgenin tespitinde kullanılan yöntemin güvenirliğinin incelenmesi. C.Ü.Hemşirelik Yüksekokulu Dergisi 2008;12(2):1-8.

26. Shepherd E. Injection technique 1: Administering drugs via the intramuscular route. Nursing Times 2018;114(8):23-5.

27. Chadwick $A$, Withnell N. How to administer intramuscular injections. Nursing Standard 2015;30(8):36-9. [CrossRef]

28. Cocoman A, Murray j. IM injections: How's your technique? World of Irish Nursing 2006;14:50-1.

29. Hunter J. Intramuscular injection techniques. Nursing Standard 2008;22(24):35-40. [CrossRef]

30. Doyle, GR, McCutcheon JA. Clinical procedures for safer patient care. Victoria, BC: BCcampus; 2015. p. 1-675.

31. Sabuncu N, Alpar SE, Karabacak Ü, Karabacak BG, Şenturan L, Orak NŞ, et al. Hemşirelik esasları temel beceri rehberi. 2nd ed. İstanbul: İstanbul Tıp Kitabevi; 2015. p. 84-7. 